\title{
Review
}

\section{Association of Intake Folate and Related Gene Polymorphisms with Breast Cancer}

\author{
Xiang CHEN $^{1,2}$, Hadji AHAMAdA ${ }^{3}$, Ting ZhAng ${ }^{4}$, Zhonghu BAI ${ }^{1,2, *}$ and ChunXin WANG ${ }^{5, * *}$ \\ ${ }^{1}$ School of Biotechnology, Jiangnan University, Wuxi, 214122, China \\ ${ }^{2}$ National Engineering Laboratory for Cereal Fermentation Technology, Jiang Nan University, China \\ ${ }^{3}$ Hematology and Clinical Biochemistry Department, Hospital EL-Maarouf, Comoros \\ ${ }^{4}$ The Affiliated Wuxi Maternity and Child Health Care Hospital of Nanjing Medical University, China \\ ${ }^{5}$ Medical Laboratory, The Affiliated Wuxi People's Hospital of Nanjing Medical University, \\ Wuxi, 214023, China \\ (Received February 14, 2019)
}

\begin{abstract}
Summary Breast cancer is one of the most common malignancies in women worldwide and is associated with a variety of risk factors. Folate and vitamin $\mathrm{B}_{12}$ are key elements of the one-carbon metabolism pathway where methylenetetrahydrofolate reductase (MTHFR) plays a significant role. Though many molecular and epidemiological studies have been performed to explore the relationship between intake folate, vitamin $\mathrm{B}_{12}$, MTHFR gene polymorphism and breast cancer risk, there is no consensus to date. By reviewing the relevant literatures and summarizing the potential effect of dietary folate intake on MTHFR genes polymorphism and breast cancer risk, we conclude that MTHFR C677T gene polymorphism is associated with breast cancer risk among Asian, but not Caucasians, and the MTHFR A1298C gene polymorphism is not a susceptibility factor of breast cancers. Concomitant low activity of MTHFR enzyme resulted from C677T gene polymorphism and low dietary folate intake is associated with increased breast cancer risk.
\end{abstract}

Key Words vitamin $\mathrm{B}_{9}$, MTHFR genes polymorphism, one-carbon metabolism pathway, DNA methylation, malignancies

\section{Background}

The interrelationship among genetics, metabolic needs and dietary adequacy is a topic of intense interest in the area of folate nutrition. Incidence of breast cancer is increasing around the world and it is still the leading cause of cancer mortality in women. About 235,303 new cases of breast cancer and approximately 40,430 deaths per year have been reported in the United States (1). The incidence of breast cancer is increasing in developing countries with a rate of 3\% to $4 \%$ (2). The etiology of breast cancer is still not fully understood. Population studies suggest that genetic factors, including gene polymorphisms and the presence of mutations might be strong risk factors that influence the individual differences in breast cancer susceptibility (3). Epidemiological studies have demonstrated an association between folate deficiency and an increased risk of a variety of cancers (4). The factors associated with the increased breast cancer risk include not only genetic mutations and lifestyle, but also nutritional status. However, folate is plentiful in vegetables and fruits while vitamin $B_{12}$ is manly stored in animal food. All these vitamins have been confirmed with reduced risk of several cancers. The crucial role of folate as the donor

\footnotetext{
*,** To whom correspondence should be addressed.

*E-mail: baizhonghu@jiangnan.edu.cn

**E-mail: Wangcx_wxph@163.com
}

of one-carbon groups in both DNA methylation and DNA synthesis may explain some of these observations (5). Methylenetetrahydrofolate reductase (MTHFR) is a type of folate-related enzymes (6). Biological functions of folate and vitamin $\mathrm{B}_{12}$ within one-carbon metabolism are to facilitate deoxynucleoside triphosphate synthesis and to provide methyl groups required for intracellular methylation reactions. To date, many molecular, epidemiological studies have been performed to evaluate the association between MTHFR gene polymorphism and different types of cancer risk in diverse populations. Methionine synthase (MTR) is a another key enzyme controlling folate metabolism. It catalyzes the remethylation of homocysteine to form methionine with the methyl donated by 5-methyltetrahydrofolate (7). Onecarbon metabolism pathway plays a key role in genome integrity, DNA methylation, and gene expression. Any aberration in this pathway might be associated with the risk of breast cancer and its phenotype (8). Mutations in its coding gene can lead to a decrease in the efficiency of purine nucleotide and thymidylate synthesis, as well as to modifications in DNA methylation profiles. However, variants of MTHFR C677T and A1298C are good candidates to study the role of genetic variants of folate metabolizing enzymes in breast cancer risk. The present review summarizes the association of MTHFR C677T and MTHFR A1298C variants with folate and vitamin $\mathrm{B}_{12}$ intake in breast cancer susceptibility to various 


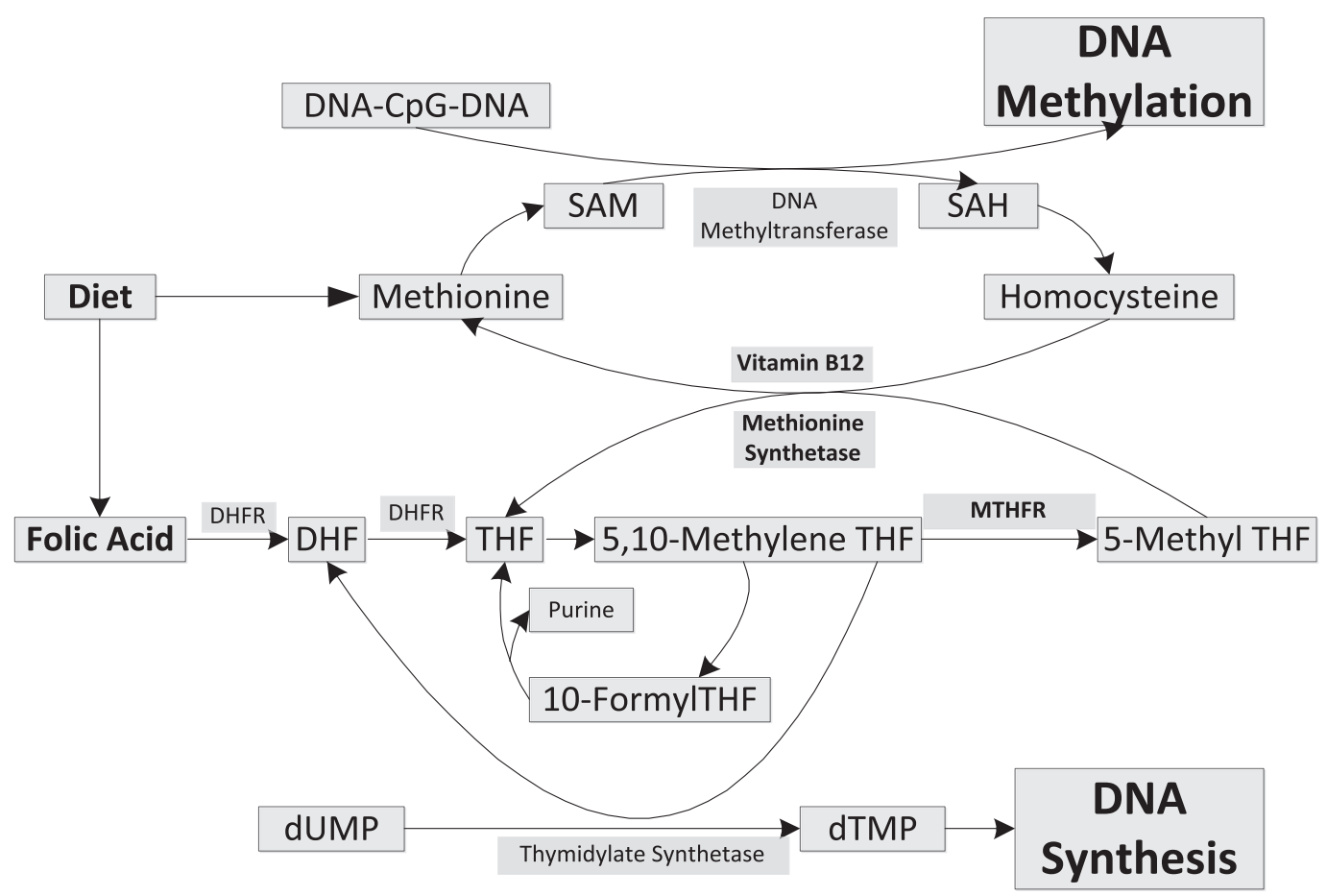

Fig. 1. Simplified scheme of folate metabolism involving DNA synthesis and methylation. DHF, dihydrofolate; THF, tetrahydrofolate; DHFR, dihydrofolate reductase; dUMP, deoxyuridine monophoshate; dTMP, deoxythymidine monophoshate; SAM, S-adenosylmethionine; SAH, S-adenosylhomocysteine.

populations.

\section{Evidence Acquisition}

Relevant studies published before 31 November 2017 was identified by searching PubMed and EMBASE. Searching terms were "intake folate," "B vitamins" and "breast cancer," in combination with "methylenetetrahydrofolate reductase" or "MTHFR" or "polymorphism." We also hand-checked the reference lists of all the included studies to make sure no study was missed. Role of folate in human metabolic processes

Folate, also known as vitamin $\mathrm{B}_{9}$, is a water-soluble vitamin and its name is derived from the Latin word folium, which means leaf. Folate is found naturally in green leafy vegetables, cereals, legumes and fruits, while folic acid is the synthetic form of the vitamin. Folate accepts one-carbon units from donor molecules and passes them on via various biosynthetic reactions (9). In their reduced form cellular folates function conjugated to a polyglutamate chain. These folates are a mixture of unsubstituted polyglutamyl tetrahydrofolates and various substituted one-carbon forms of tetrahydrofolate (e.g., 10-formyl, 5,10-methylene, and 5-methyl) (Fig. 1 ). The reduced forms of the vitamin, particularly the unsubstituted dihydro and tetrahydro forms, are unstable chemically. They are easily split between the C-9 and N-10 bond to yield a substituted pteridine and $p$-aminobenzoylglutamate, which have no biologic activity (10). Substituting a carbon group at N-5 or N-10 decreases the tendency of the molecule to split; however, the substituted forms are also susceptible to oxidative chemical rearrangements and, consequently, loss of activity. The folate found in food consists of a mixture of reduced folate polyglutamates. However, folic acid is reduced in cells by the enzyme dihydrofolate reductase to the di- and tetrahydro forms. This takes place within the intestinal mucosal cells, and 5-methyltetrahydrofolate is released into the plasma. Functional folates have onecarbon groups derived from several metabolic precursors (e.g., serine, $\mathrm{N}$-formino-L-glutamate, folate, etc.). With 10-formyltetrahydrofolate the formyl group is incorporated sequentially into $\mathrm{C}-2$ and $\mathrm{C}-8$ of the purine ring during its biosynthesis. Likewise the conversion of deoxyuridylate (a precursor to RNA) into thymidylate (a precursor to DNA) is catalyzed by thymidylate synthase, which requires 5,10-methylenetetrahydrofofate. Thus, folate in its reduced and polyglutamylated forms is essential for the DNA biosynthesis cycle shown in Fig. 1. The DNA and methylation cycles both regenerate tetrahydrofolate. However, there is a considerable amount of catabolism of folate and a small loss of folate via excretion from the urine, skin, and bile (11). There is a need to replenish the body's folate content by uptake from the diet. If there is inadequate dietary folate, the activity of both the DNA and the methylation cycles will be reduced. A decrease in the former will reduce DNA biosynthesis and thereby reduce cell division.

Association of folate with breast cancer

Folate is involved in DNA synthesis, repair, and methylation. It has been hypothesized that high intake of folate may reduce the risk of human cancers, including breast cancer. In fact, breast cancer begins in any part of breast, caused by abnormal cells growth and division. Literature revealed that folate metabolism 
imbalance may be involved in predisposition to cancer. Folate metabolism pathway regulates the intracellular folate pool for synthesis and methylation of DNA (12). The serum folate enters into tissue cells through folate receptors, and then it was turned into tetrahydrofolate via dihydrofolate reductase. Methylenetetrahydrofolate reductase (MTHFR) then transformed the 5,10-methylenetetrahydrofolate into 5-methyltetrahydrofolate, which supplied a methyl group for transformation of homocysteine to methionine in a reaction catalyzed by methionine synthase (MTR) (13). During the past several decades, many epidemiological studies have been conducted to evaluate the relationship between folate intake or blood folate levels and breast cancer risk (Table 1). A more pronounced inverse association between folate intake and breast cancer risk was observed among women who consumed high levels of folate cofactors (methionine, vitamin $\mathrm{B}_{12}$, and vitamin $\mathrm{B}_{6}$ ) than those whose intake levels of these nutrients were low (14). However, there is still no consensus on such a relationship. Several studies have suggested that high folate intake or high serum folate level may reduce the risk of breast cancer, especially for those with high alcohol consumption while some other studies found no such associations. Investigators used data from a population based case-control study of breast cancer conducted in urban Shanghai to evaluate the association of dietary folate intake and breast cancer risk, their studies found evidence of a decreased breast cancer risk associated with high folate consumption among women who do not regularly consume alcohol (14). This relationship was especially apparent among subjects who also consumed higher amounts of methionine, vitamin $\mathrm{B}_{12}$, or vitamin $\mathrm{B}_{6}$. One study found that folate intake was related to reduced breast cancer risk only among premenopausal women, whereas an inverse association was observed in postmenopausal women (15), particularly those who drank alcohol regularly. However, only a few studies have examined the association of dietary folate intake with breast cancer risk, and the results from these studies have been inconsistent (16). In addition, inadequate levels of serum folate, vitamin $\mathrm{B}_{6}$, and vitamin $\mathrm{B}_{12}$ have been associated with increased breast cancer risk $(17,18)$. These vitamins all participate as coenzymes in the synthesis of purines and thymidylate for DNA synthesis. Altered DNA methylation, disruption of DNA integrity, and interference with DNA repair are hypothesized mechanisms by which imbalances in folate and other B vitamins may influence nucleic acid metabolism and participate in carcinogenesis (19). The relation of folate intake with breast cancer risk has been investigated in five large prospective cohorts, most of which have not found an overall association of folate intake and breast cancer risk $(15,16,20-22)$. However, in three of these studies, low folate intake seemed to increase breast cancer risk among women with high alcohol intake $(15,16,22)$. This apparent contradiction may be explained by differences in folate intake between populations. Few epidemiologic studies have evaluated vitamin $\mathrm{B}_{6}$ and vitamin $\mathrm{B}_{12}$ and breast can- cer risk. In addition, the association of micronutrient intake and breast cancer seems to differ by menopausal status and levels of other micronutrients $(23,24)$. It has been reported that among individuals with prevalence of homozygous TT genotype for the 677CT transition in the MTHFR gene with low folate intake has been associated with more substantial increased breast cancer risk than those with other genotypes (24).

Association of MTHFR gene polymorphisms with breast cancer

MTHFR gene polymorphisms. Breast cancer is a multifactorial disease, involving biological, endocrine factors, reproductive life, behavior and lifestyle. It is the leading cause of women death worldwide due to it metastasis to other organs. Development of human breast cancers is a multistage process, arising from genetic alterations that drive the transformation of normal mammary epithelial cells into highly malignant derivatives. Epidemiological evidence shows that folate deficiency is a breast cancer risk factor (22). MTHFR is a key enzyme in folate metabolism and regulates the intracellular folate pool for DNA synthesis and methylation (Fig. 1) (25). Two common allele variants of the MTHFR gene are C677T and A1298C, the point mutation of $\mathrm{C}$ to $\mathrm{T}$ and $\mathrm{A}$ to $\mathrm{C}$ may decrease the activity of enzyme (26). Heterozygous and homozygous carriers of the $677 \mathrm{~T}$ allele variant reduced the activity of enzyme to $30-40 \%$ and $60-70 \%$, respectively (27). The effect of the $1298 \mathrm{C}$ allele variant is less severe and homozygous carriers of this allele have a moderate $30-40 \%$ reduction of the enzyme activity, yet its function remains controversial (28). Furthermore, people who are heterozygous at both loci, C677T and A1298C, experience an intermediate activity loss of $40-50 \%$ (29). It has been shown that the $677 \mathrm{~T}$ variant increases the plasma homocysteine concentration in humans and reduces DNA methylation in cancer patients, which indicates a reduced synthesis of methionine and a more limited availability of the methyl donor, $S$-adenosyl-methionine, in the presence of low activity T allele (30). Many studies investigated the association between the two genotypes and breast cancer incidence. Although significant associations were observed in some studies, a clear linkage between MTHFR gene polymorphisms and the risk to develop breast cancer has not been established (31). Recently, the two MTHFR genotypes were found to modulate the chemosensitivity of cancer cells to 5-fluorouracil and methotrexate. It was stated that two functional polymorphisms in the MTHFR gene affect the survival of ER-negative breast cancer patients (32). We did not observe significant interactions between the two SNPs and chemotherapy on breast cancer survival but observed interactions with race or ethnicity and alcohol consumption.

Prospective from meta-analysis and case-control studies. The gene encoding MTHFR is located in chromosome 1p36.3 and has several polymorphisms, the most common ones are MTHFR C677T and MTHFR A1298C. The point mutation of $\mathrm{C}$ to $\mathrm{T}$ at nucleotide 677 of the MTHFR gene (Ala222Val, rs1801133) causes an ala- 
CHen X et al.

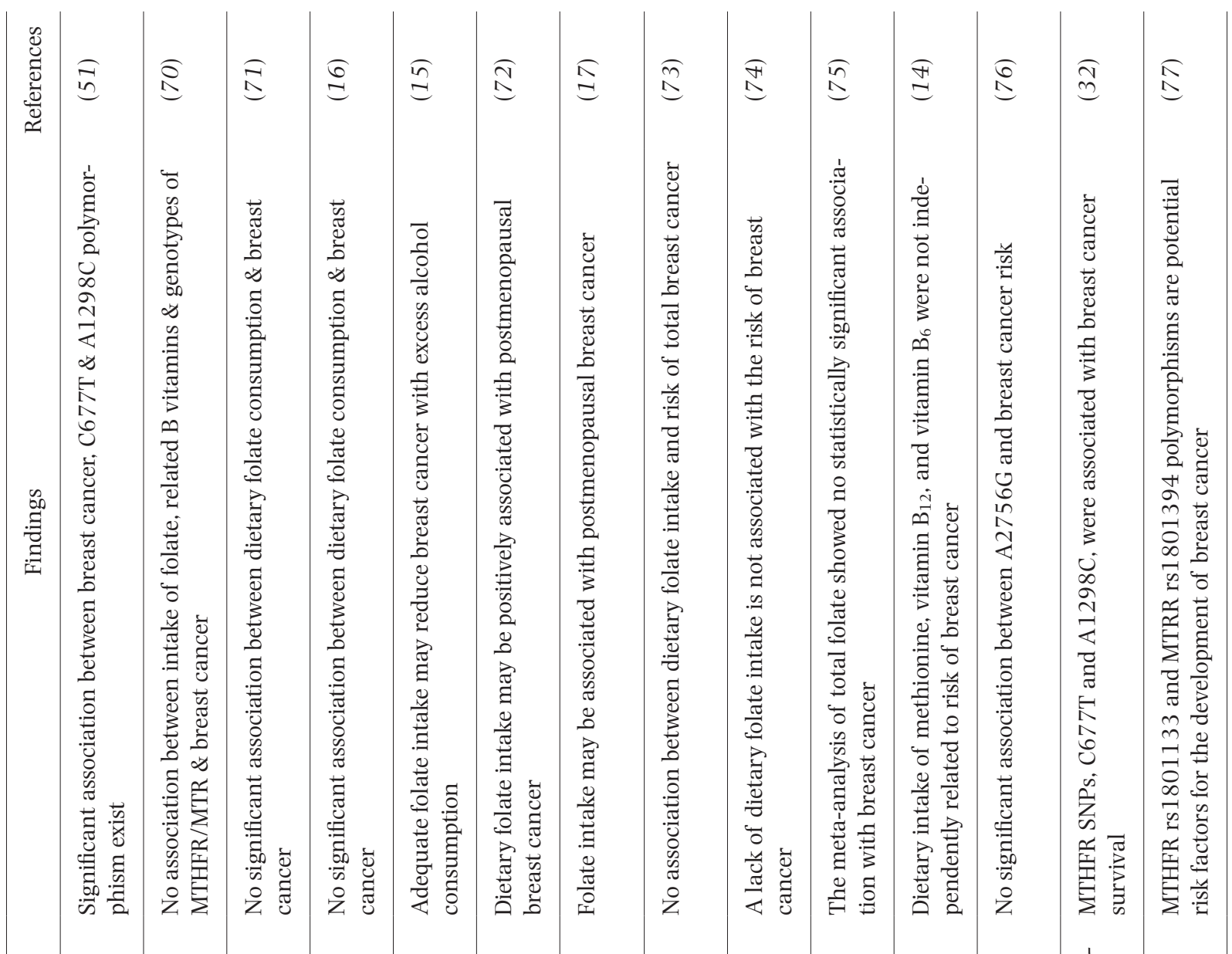

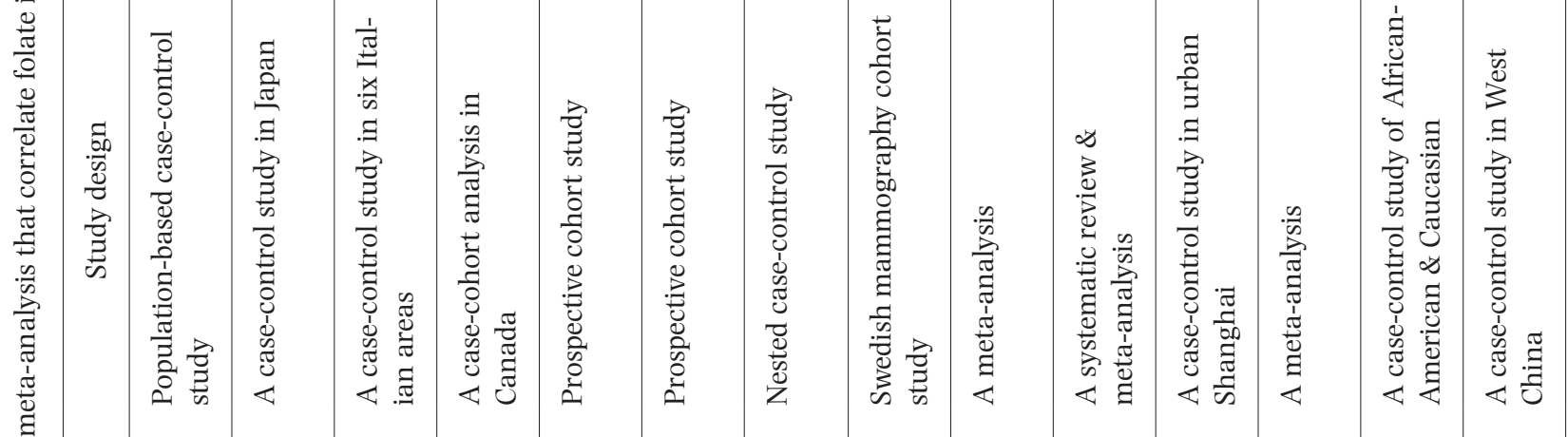

를

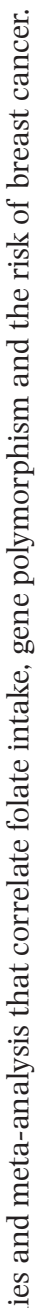


Intake Folate and Related Gene Polymorphisms with Breast Cancer

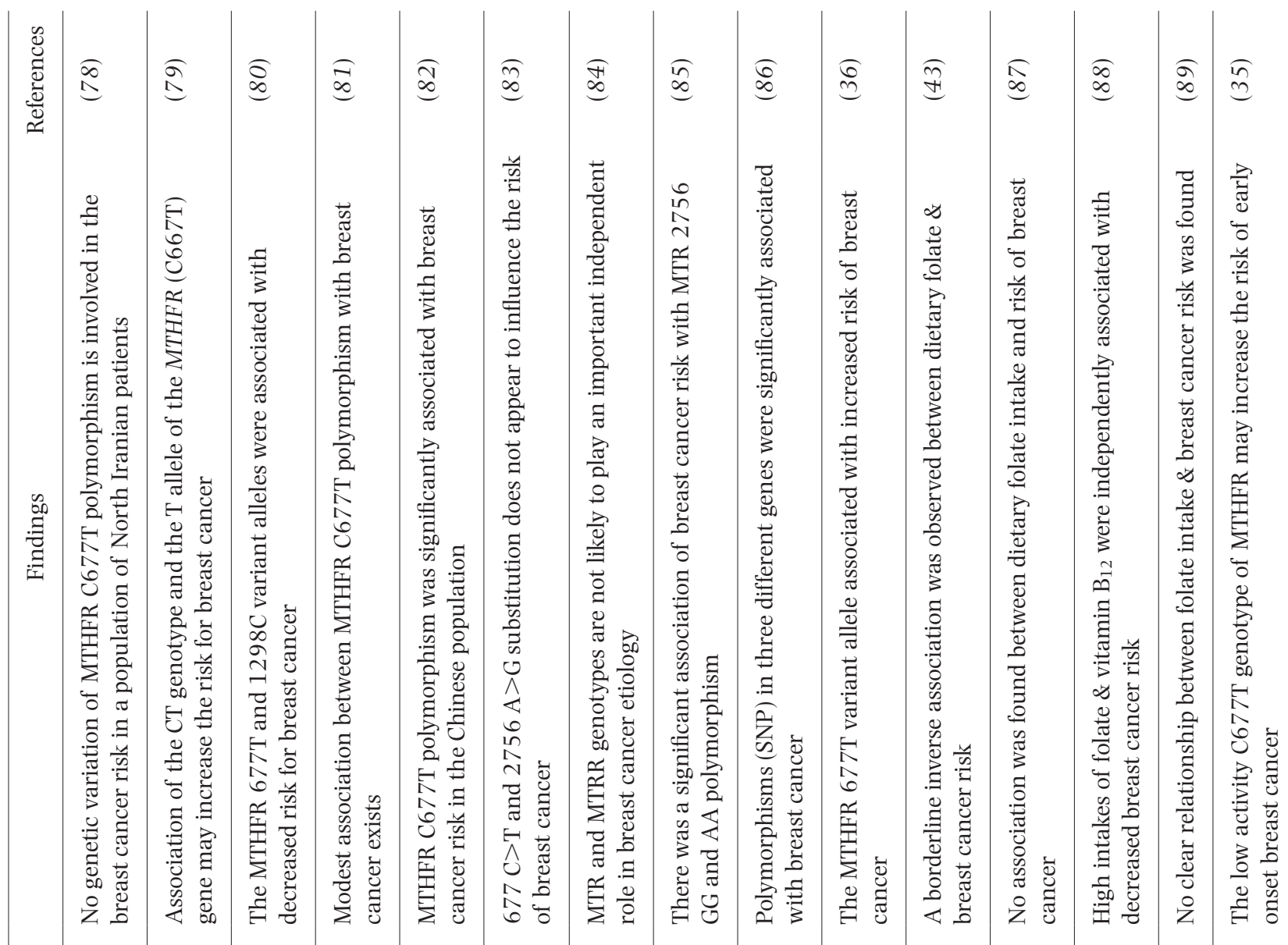

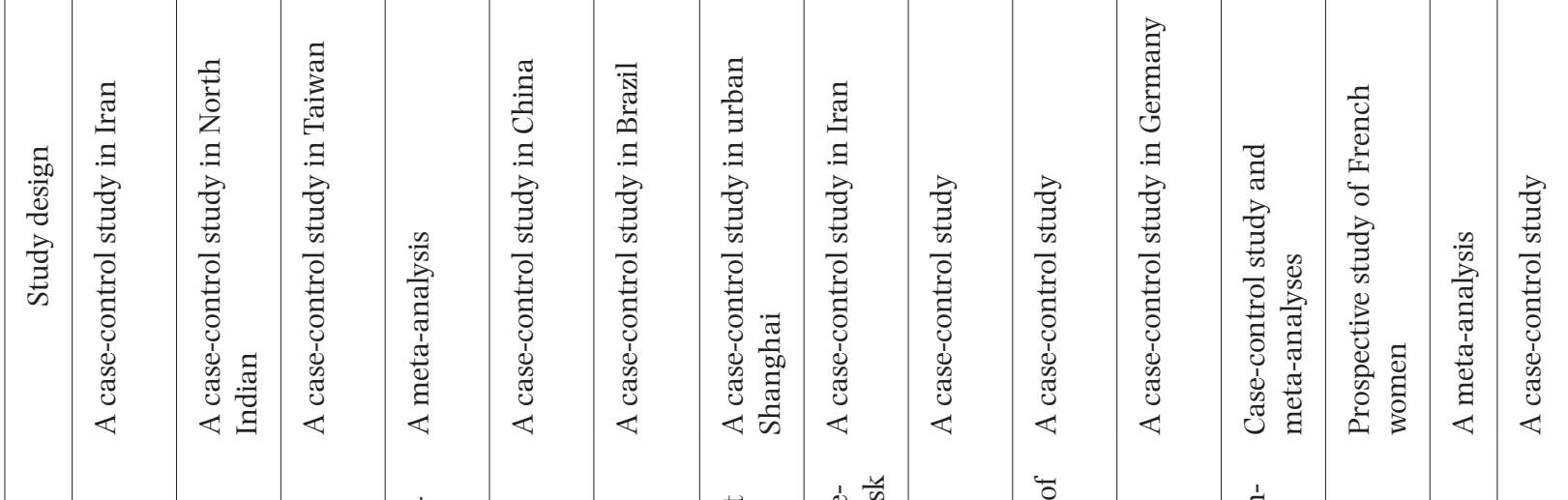

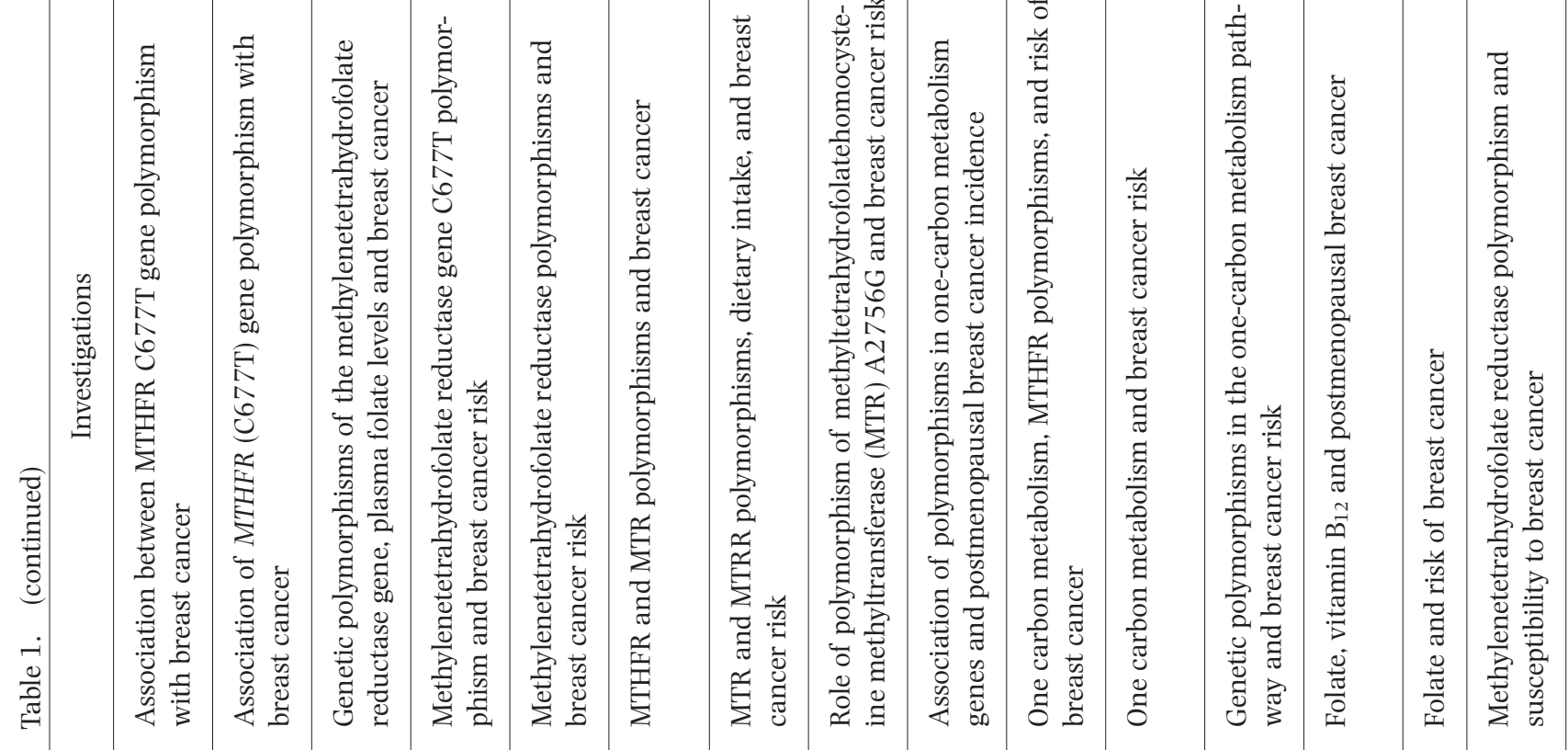


Chen X et al.

\begin{tabular}{|c|c|c|c|c|c|c|c|c|c|c|c|c|c|}
\hline$\stackrel{2}{8}$ & $\widehat{\sigma}$ & $\widehat{\sigma}$ & $\widehat{\sigma}$ & Fु & $\stackrel{\infty}{=}$ & $\sqrt{2}$ & $\overline{0}$ & $\sigma^{\circ}$ & $\hat{a}$ & $\stackrel{\sigma}{\sigma}^{\infty}$ & & $\cong$ & \\
\hline 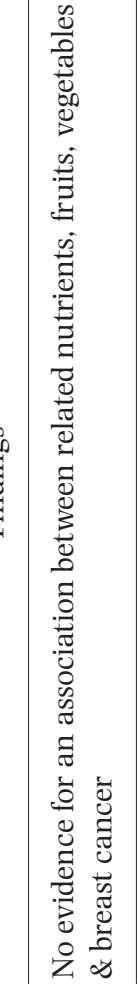 & 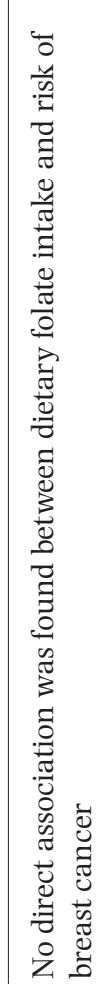 & 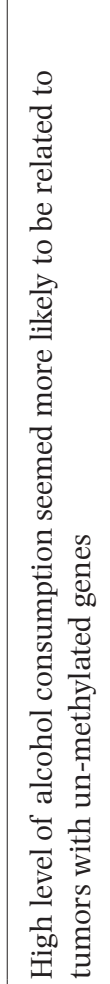 & 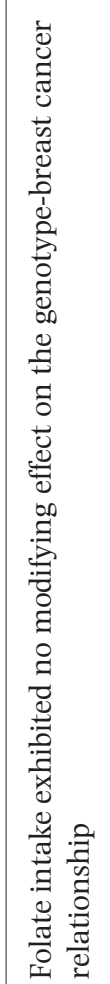 & 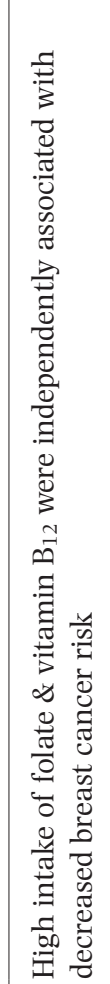 & 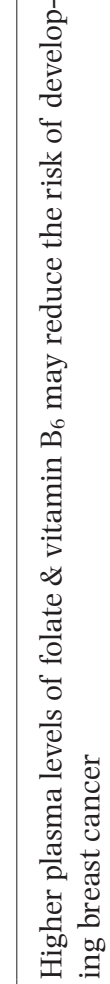 & 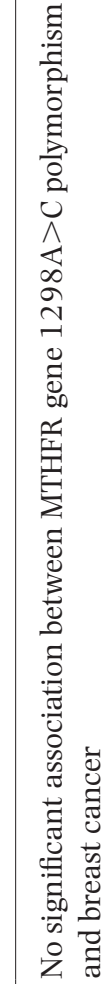 & 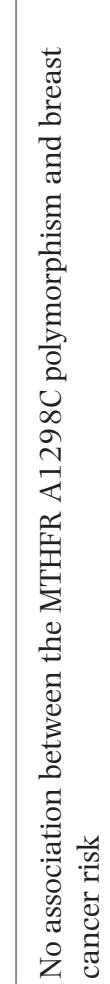 & 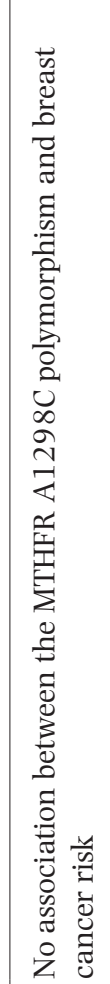 & 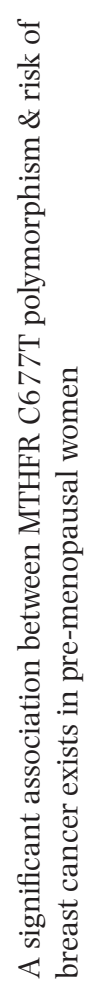 & 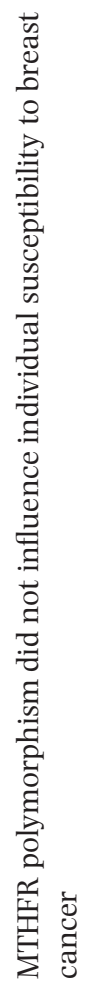 & & 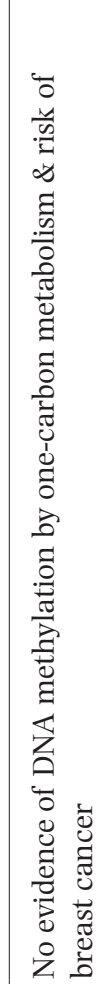 & \\
\hline
\end{tabular}

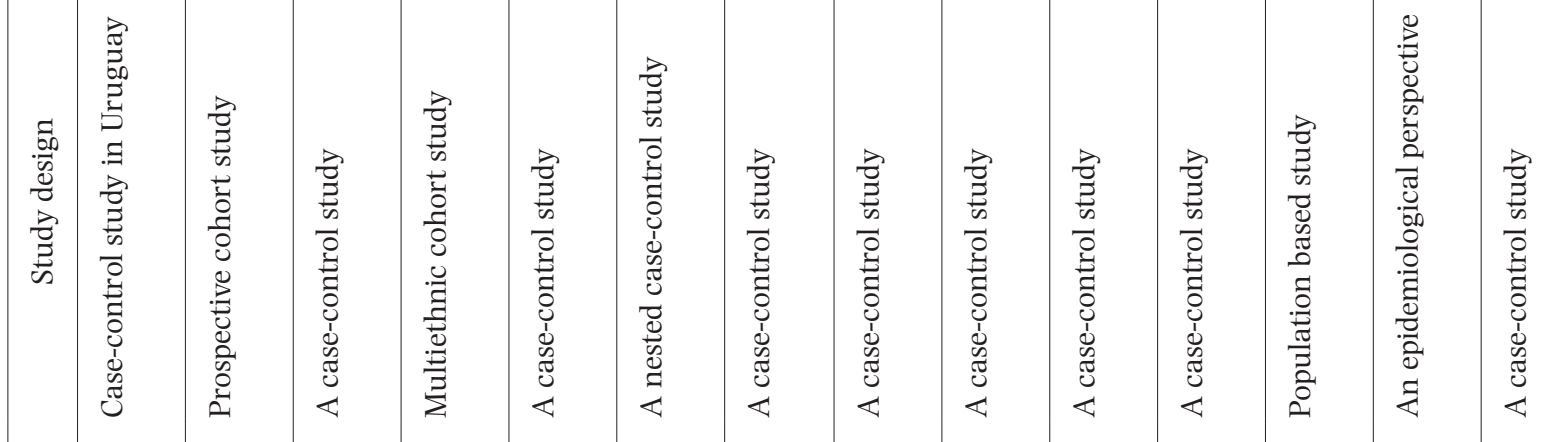

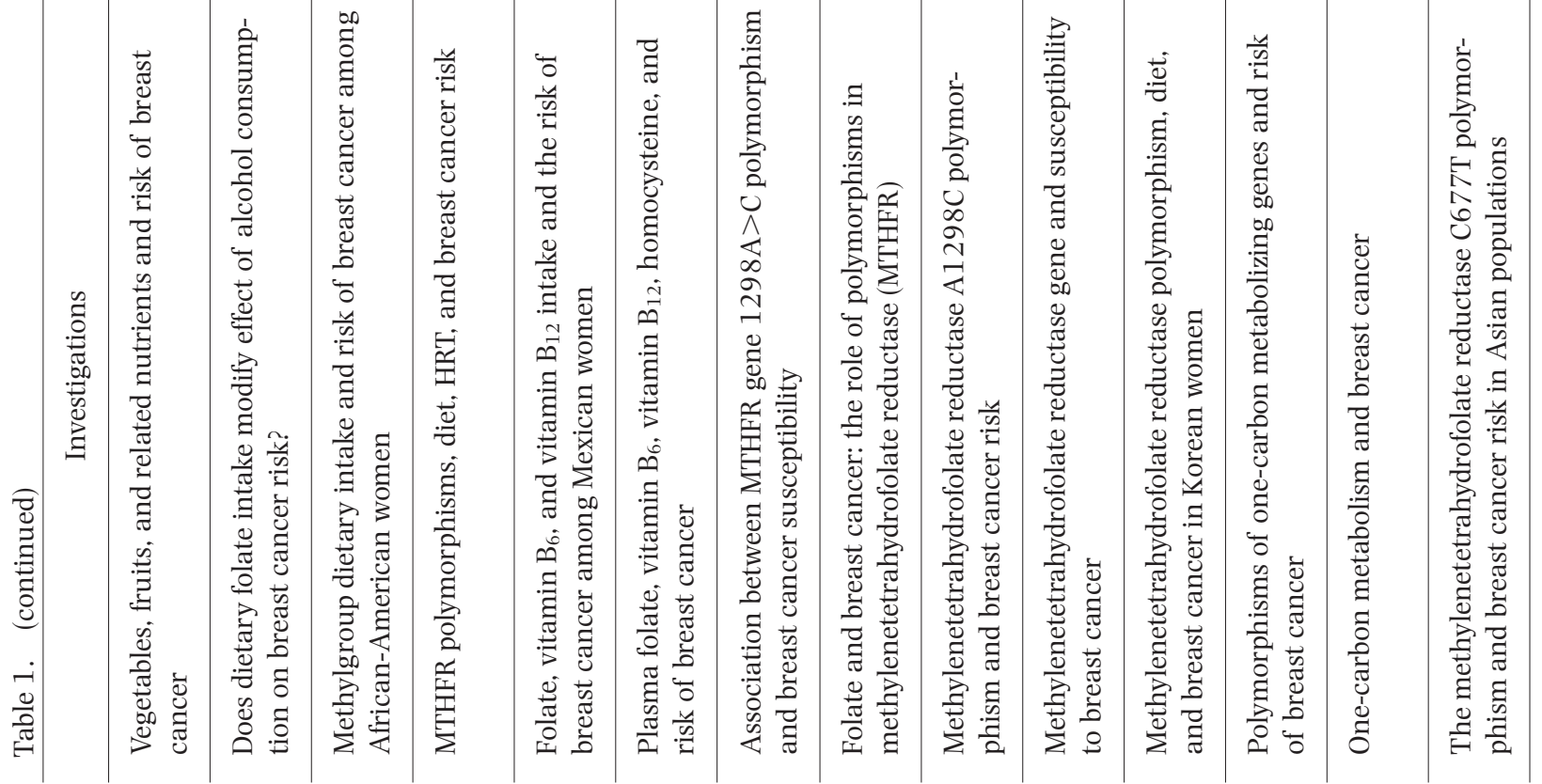


Table 2. Related methylene tetrahydrofolate reductase C677T polymorphism and breast cancer in various populations.

\begin{tabular}{lll}
\hline \multicolumn{1}{c}{ Population } & \multicolumn{1}{c}{ Findings } & \multicolumn{1}{c}{ Reference } \\
\hline $\begin{array}{l}\text { Chinese, Iranian, American, European, Mexican, } \\
\text { Jordanian, Turkish, Kazakh, Indian \& East Asian }\end{array}$ & $\begin{array}{l}\text { Association with breast cancer } \\
\text { risk }\end{array}$ & $(40,41,48,51,52,55-60,62,101)$ \\
\hline Turkish \& British & $\begin{array}{l}\text { Association with pre-menopausal } \\
\text { breast cancer risk }\end{array}$ & $(35,46,47)$ \\
\hline Swedish, Japanese, Brazilian \& East Asian & $\begin{array}{l}\text { Association with post-menopausal } \\
\text { breast cancer }\end{array}$ & $(37,39,49)$ \\
\hline $\begin{array}{l}\text { Caucasians, Canadian, Spanish, German \& } \\
\text { Russian }\end{array}$ & $\begin{array}{l}\text { Lack of association with the risk } \\
\text { of breast cancer }\end{array}$ & $(38,42-45,59,60)$ \\
\hline
\end{tabular}

nine to valine change at position 222 of the polypeptide that result in a thermolabile enzyme with reduced catalytic activity (33). Each copy of the $677 \mathrm{~T}$ allele results in a 35\% decreased MTHFR activity. In homozygous genotype of MTHFR 677TT, the MTHFR enzyme has $30 \%$ full activity. However, in the presence of heterozygous genotype of MTHFR $677 \mathrm{CT}$, the activity of enzyme is $65 \%$ (34). There are controversial reports related to the role of MTHFR C677T variants in susceptibility to breast cancer in various populations (Table 1 and Table 2). Studies found an association between the increased risk of breast cancer with MTHFR C677T polymorphism in population of England, Mexican, south-eastern European women, and in population of Swedish and Brazilian post-menopausal women (35-41). In contrast, in a large sample of Canadian, Spanish, German and West Siberian Region of Russia women, the MTHFR C677T was not a risk factor for breast cancer (42-45). There are several studies from Asian populations reporting the influence of MTHFR C677T variants in breast cancer susceptibility, but also with inconsistency. It seems that the MTHFR 677TT genotype was associated with breast cancer in Chinese, Iranians, Jordanese, Turkish, Indian, Kazakhstan, and in population of Japanese post-menopausal women while unassociated with Thai, Pakistani and Syrian women (46-58). The higher risk of breast cancer in post-menopausal women than the premenopausal women could be due to different expression of estrogen receptor in the first group and the possible estrogen receptor gene misregulation in the presence of MTHFR 677TT genotype (49). In two meta-analyses, strong association was found between this polymorphism and the risk of breast cancer in East Asian population. However, the meta-analysis did not find such association in Caucasian population $(59,60)$. The latter meta-analysis suggested the risk of breast cancer was significantly associated with postmenopausal status (60). Also, two recent meta-analyses suggested a significant relation between MTHFR 677TT genotype and breast cancer risk in Asian populations (61, 62). The association of MTHFR C677T polymorphism with hypomethylation of DNA might suggest a role for this polymorphism in the development of cancer. According to the literature, it seems that MTHFR C677T is associated with breast cancer risk among Asian populations, especially East Asians, but not in Caucasian populations. The inconsistent findings of association between the MTHFR C677T in various populations may underlie differences in ethnicity, lifestyle, and disease prevalence as well as possible limitations due to the relatively small sample size. There are a wide variation in the $\mathrm{T}$ allele frequencies of control resources in Asians (0.396), Indians (0.132), Caucasians (0.326), Middle Eastern countries (0.201), and Africans (0.196) that might account for the discrepancy in association between the MTHFR C677T polymorphism and cancer risk in different ethnic groups (62).

Association of DNA methylation with breast cancer

Diets deficient in methyl group donors (choline, folate, methionine, and vitamin $\mathrm{B}_{12}$ ) are associated with spontaneous and chemically induced development of hepatocellular carcinoma in rats (63). Folate, in the form of 5-methyltetrahydrofolate, is involved in remethylation of homocysteine to methionine, which is a precursor of $S$-adenosylmethionine (SAM), the primary methyl group donor for most biological methylations including that of DNA (Fig. 1). After transferring the methyl group, SAM is converted to $S$-adenosylhomocysteine (SAH), a potent inhibitor of most SAM-dependent methyltransferases (64). Cravo et al. firstly proposed that a mechanism by which folate deficiency enhances carcinogenesis might be through an induction of genomic DNA hypomethylation based on the biochemical function of folate in mediating one-carbon transfer and on evidence from animal experiments that demonstrated methyl group donor deficiency-induced DNA hypomethylation (65). Thus, several human studies have investigated the correlations between DNA methylation and folate status. In human subjects with normal folate status, no significant correlations between genomic lymphocyte DNA methylation and RBC folate and plasma homocysteine concentrations were observed (66). Therefore, DNA hypomethylation was proposed as one of the possible mechanisms for the development of hepatocellular carcinoma associated with methyl-deficient diets (67). Furthermore, there is evidence that folate status influ- 
ences DNA methylation through an interaction with the MTHFR C677T polymorphism (5). MTHFR is a critical enzyme in folate metabolism that catalyzes the irreversible conversion of 5,10-methylenetetrahydrofolate to 5-methyltetrahydrofolate, thereby playing an important role in DNA synthesis, maintenance of nucleotide pool balance, and DNA methylation (Fig. 1). Christensen et al. examined a cohort of women with breast cancer and the DNA methylation level at 1413 sites in 733 genes (68). They found that dietary folate intake was associated with DNA methylation class membership in primary breast tumors. Genomic DNA methylation in peripheral blood mononuclear cells was recently shown to directly correlate with folate status and inversely correlate with plasma homocysteine levels. MTHFR TT genotypes had a diminished level of genomic DNA methylation compared with those with the CC wild-type (69). When analyzed according to folate status, however, only the TT subjects with low levels of folate accounted for the diminished genomic DNA methylation.

\section{Conclusion}

Folate and MTHFR gene are key elements of the onecarbon metabolism pathway which are significiently associated with breast cancers. The association between folate and breast cancer risk largely rely on MTHFR gene polymorphism. MTHFR C677T is associated with breast cancer risk among Asians but not Caucasians, and MTHFR A1298C is not a susceptibility factor of breast cancer. Lower activity of MTHFR enzyme in the presence of C677T allele and low dietary folate intake may result in uracil disincorporation in DNA and breast cancer development. As vitamin absorption and utilization efficiency vary considerably in different populations. Further studies on relationship between serum folate and MTHFR gene polymorphism with breast cancers should be conducted.

\section{Disclosure of state of COI}

No potential conflicts of interest were disclosed.

\section{Grant support}

This work was supported by Jiangsu key R \& D program (BE2018621), the national first-class discipline program of Light Industry Technology and Engineering (LITE2018-24), the Collaborative Innovation Center of Jiangsu Modern Industrial Fermentation, the 111 Project (111-2-06), the Priority Academic Program Development of Jiangsu Higher Education Institutions.

\section{REFERENCES}

1) Sanjari Moghaddam A, Nazarzadeh M, Noroozi R, Darvish H, Mosavi Jarrahi A. 2016. XRCC1 and OGG1 gene polymorphisms and breast cancer: a systematic review of literature. Iran J Cancer Prev 9(1): e3467.

2) Yari K, Rahimi Z, Moradi MT, Rahimi Z. 2014. The MMP2-735 C allele is a risk factor for susceptibility to breast cancer. Asian Pac J Cancer Prev 15(15): 6199-6203.

3) Yari K, Rahimi Z, Payandeh M, Rahimi Z. 2015. MMP-7 A-181G polymorphism in breast cancer patients from Western Iran. Breast Care (Basel) 10(6): 398-402.
4) Choi SW, Mason JB. 2000. Folate and carcinogenesis: an integrated scheme. J Nutr 130(2): 129-132.

5) Kim YI. 1999. Folate and carcinogenesis: evidence, mechanisms, and implications. J Nutr Biochem 10(2): 66-88.

6) Friedman G, Goldschmidt N, Friedlander Y, Ben-Yehuda A, Selhub J, Babaey S, Mendel M, Kidron M, Bar-On H. 1999. A common mutation A1298C in human methylenetetrahydrofolate reductase gene: association with plasma total homocysteine and folate concentrations. $J$ Nutr 129(9): 1656-1661.

7) Fodinger M, Horl WH, Sunder-Plassmann G. 2000. Molecular biology of 5,10-methylenetetrahydrofolate reductase. J Nephrol 13(1): 20-33.

8) Naushad SM, Pavani A, Rupasree Y, Divyya S, Deepti S, Digumarti RR, Gottumukkala SR, Prayaga A, Kutala VK. 2012. Association of aberrations in one-carbon metabolism with molecular phenotype and grade of breast cancer. Mol Carcinog 51 (Suppl 1): E32-41.

9) Scott J, Weir D. 1994. Folate/vitamin B12 inter-relationships. Essays Biochem 28: 63-72.

10) Blakley RL. 1969. Biochemistry of Folic Acid and Related Pteridines. North-Holland Publishing, Amsterdam.

11) McPartlin J, Halligan A, Scott JM, Darling M, Weir DG. 1993. Accelerated folate breakdown in pregnancy. Lancet 341(8838): 148-149.

12) Das PM, Singal R. 2004. DNA methylation and cancer. J Clin Oncol 22(22): 4632-4642.

13) Biselli JM, Goloni-Bertollo EM, Haddad R, Eberlin MN, Pavarino-Bertelli EC. 2008. The MTR A2756G polymorphism is associated with an increase of plasma homocysteine concentration in Brazilian individuals with Down syndrome. Braz J Med Biol Res 41(1): 34-40.

14) Shrubsole MJ, Jin F, Dai Q, Shu XO, Potter JD, Hebert JR, Gao YT, Zheng W. 2001. Dietary folate intake and breast cancer risk: results from the Shanghai Breast Cancer Study. Cancer Res 61(19): 7136-7141.

15) Zhang S, Hunter DJ, Hankinson SE, Giovannucci EL, Rosner BA, Colditz GA, Speizer FE, Willett WC. 1999. A prospective study of folate intake and the risk of breast cancer. JAMA 281(17): 1632-1637.

16) Rohan TE, Jain MG, Howe GR, Miller AB. 2000. Dietary folate consumption and breast cancer risk. J Natl Cancer Inst 92(3): 266-269.

17) Wu K, Helzlsouer KJ, Comstock GW, Hoffman SC, Nadeau MR, Selhub J. 1999. A prospective study on folate, B12, and pyridoxal 5'-phosphate (B6) and breast cancer. Cancer Epidemiol Biomarkers Prev 8(3): 209-217.

18) Zhang SM, Willett WC, Selhub J, Hunter DJ, Giovannucci EL, Holmes MD, Colditz GA, Hankinson SE. 2003. Plasma folate, vitamin B6, vitamin B12, homocysteine, and risk of breast cancer. J Natl Cancer Inst 95(5): 373-380.

19) Mason JB. 2003. Biomarkers of nutrient exposure and status in one-carbon (methyl) metabolism. J Nutr 133 (Suppl 3(3)): 941s-947s.

20) Cho E, Spiegelman D, Hunter DJ, Chen WY, Stampfer MJ, Colditz GA, Willett WC. 2003. Premenopausal fat intake and risk of breast cancer. J Natl Cancer Inst 95(14): 1079-1085.

21) Feigelson HS, Jonas CR, Robertson AS, McCullough ML, Thun MJ, Calle EE. 2003. Alcohol, folate, methionine, and risk of incident breast cancer in the American Cancer Society Cancer Prevention Study II Nutrition Cohort. Cancer Epidemiol Biomarkers Prev 12(2): 161-164. 
22) Sellers TA, Kushi LH, Cerhan JR, Vierkant RA, Gapstur SM, Vachon CM, Olson JE, Therneau TM, Folsom AR. 2001. Dietary folate intake, alcohol, and risk of breast cancer in a prospective study of postmenopausal women. Epidemiology 12(4): 420-428.

23) Gaudet MM, Britton JA, Kabat GC, Steck-Scott S, Eng SM, Teitelbaum SL, Terry MB, Neugut AI, Gammon MD. 2004. Fruits, vegetables, and micronutrients in relation to breast cancer modified by menopause and hormone receptor status. Cancer Epidemiol Biomarkers Prev 13(9): 1485-1494.

24) Shrubsole MJ, Gao YT, Cai Q, Shu XO, Dai Q, Hébert JR, Jin F, Zheng W. 2004. MTHFR polymorphisms, dietary folate intake, and breast cancer risk: results from the Shanghai Breast Cancer Study. Cancer Epidemiol Biomarkers Prev 13(2): 190-196.

25) Ueland PM, Hustad S, Schneede J, Refsum H, Vollset SE. 2001. Biological and clinical implications of the MTHFR C677T polymorphism. Trends Pharmacol Sci 22(4): 195-201.

26) Frosst P, Blom HJ, Milos R, Goyette P, Sheppard CA, Matthews RG, Boers GJ, den Heijer M, Kluijtmans LA, van den Heuvel LP. 1995. A candidate genetic risk factor for vascular disease: a common mutation in methylenetetrahydrofolate reductase. Nat Genet 10(1): 111-113.

27) Sohn KJ, Croxford R, Yates Z, Lucock M, Kim YI. 2004. Effect of the methylenetetrahydrofolate reductase C677T polymorphism on chemosensitivity of colon and breast cancer cells to 5-fluorouracil and methotrexate. J Natl Cancer Inst 96(2): 134-144.

28) Yamada K, Chen Z, Rozen R, Matthews RG. 2001. Effects of common polymorphisms on the properties of recombinant human methylenetetrahydrofolate reductase. Proc Natl Acad Sci USA 98(26): 14853-14858.

29) Weisberg I, Tran P, Christensen B, Sibani S, Rozen R. 1998. A second genetic polymorphism in methylenetetrahydrofolate reductase (MTHFR) associated with decreased enzyme activity. Mol Genet Metab 64(3): 169-172.

30) Paz MF, Avila S, Fraga MF, Pollan M, Capella G, Peinado MA, Sanchez-Cespedes M, Herman JG, Esteller M. 2002. Germ-line variants in methyl-group metabolism genes and susceptibility to DNA methylation in normal tissues and human primary tumors. Cancer Res 62(15): 4519-4524.

31) Sharp L, Little J, Schofield AC, Pavlidou E, Cotton SC, Miedzybrodzka Z, Baird JO, Haites NE, Heys SD, Grubb DA. 2002. Folate and breast cancer: the role of polymorphisms in methylenetetrahydrofolate reductase (MTHFR). Cancer Lett 181(1): 65-71.

32) Martin DN, Boersma BJ, Howe TM, Goodman JE, Mechanic LE, Chanock SJ, Ambs S. 2006. Association of MTHFR gene polymorphisms with breast cancer survival. BMC Cancer 6: 257.

33) Goyette P, Sumner JS, Milos R, Duncan AM, Rosenblatt DS, Matthews RG, Rozen R. 1994. Human methylenetetrahydrofolate reductase: isolation of cDNA, mapping and mutation identification. Nat Genet 7(2): 195-200.

34) Lopez-Cortes A, Jaramillo-Koupermann G, Muñoz MJ, Cabrera A, Echeverría C, Rosales F, Vivar N, Paz-y-Miño C. 2013. Genetic polymorphisms in MTHFR (C677T, A1298C), MTR (A2756G) and MTRR (A66G) genes associated with pathological characteristics of prostate cancer in the Ecuadorian population. Am J Med Sci 346(6): 447-454.
35) Campbell IG, Baxter SW, Eccles DM, Choong DY. 2002. Methylenetetrahydrofolate reductase polymorphism and susceptibility to breast cancer. Breast Cancer Res 4(6): R14.

36) Chen J, Gammon MD, Chan W, Palomeque C, Wetmur JG, Kabat GC, Teitelbaum SL, Britton JA, Terry MB, Neugut AI, Santella RM. 2005. One-carbon metabolism, MTHFR polymorphisms, and risk of breast cancer. Cancer Res 65(4): 1606-1614.

37) Ericson U, Sonestedt E, Ivarsson MI, Gullberg B, Carlson J, Olsson H, Wirfält E. 2009. Folate intake, methylenetetrahydrofolate reductase polymorphisms, and breast cancer risk in women from the Malmo Diet and Cancer cohort. Cancer Epidemiol Biomarkers Prev 18(4): 1101-1110.

38) Platek ME, Shields PG, Marian C, McCann SE, Bonner MR, Nie J, Ambrosone CB, Millen AE, Ochs-Balcom HM, Quick SK, Trevisan M, Russell M, Nochajski TH, Edge SB, Freudenheim JL. 2009. Alcohol consumption and genetic variation in methylenetetrahydrofolate reductase and 5-methyltetrahydrofolate-homocysteine methyltransferase in relation to breast cancer risk. Cancer Epidemiol Biomarkers Prev 18(9): 2453-2459.

39) de Cassia Carvalho Barbosa R, da Costa DM, Cordeiro DE, Vieira AP, Rabenhorst SH. 2012. Interaction of MTHFR C677T and A1298C, and MTR A2756G gene polymorphisms in breast cancer risk in a population in Northeast Brazil. Anticancer Res 32(11): 4805-4811.

40) Papandreou CN, Doxani C, Zdoukopoulos N, Vlachostergios PJ, Hatzidaki E, Bakalos G, Ziogas DC, Koufakis T, Zintzaras E. 2012. Evidence of association between methylenetetrahydrofolate reductase gene and susceptibility to breast cancer: a candidate-gene association study in a South-eastern European population. DNA Cell Biol 31(2): 193-198.

41) Ramos-Silva A, Figuera LE, Soto-Quintana OM, PueblaPérez AM, Ramírez-Patiño R, Gutiérrez-Hurtado I, Carrillo-Moreno DI, Zúñiga-González GM, Dávalos-Rodríguez IP, Gallegos-Arreola MP. 2015. Association of the C677T polymorphism in the methylenetetrahydrofolate reductase gene with breast cancer in a Mexican population. Genet Mol Res 14(2): 4015-4026.

42) Kotsopoulos J, Zhang WW, Zhang S, McCready D, Trudeau M, Zhang P, Sun P, Narod SA. 2008. Polymorphisms in folate metabolizing enzymes and transport proteins and the risk of breast cancer. Breast Cancer Res Treat 112(3): 585-593.

43) Justenhoven C, Hamann U, Pierl CB, Rabstein S, Pesch B, Harth V, Baisch C, Vollmert C, Illig T, Brüning T, Ko Y, Brauch H. 2005. One-carbon metabolism and breast cancer risk: no association of MTHFR, MTR, and TYMS polymorphisms in the GENICA study from Germany. Cancer Epidemiol Biomarkers Prev 14(12): 3015-3018.

44) Henriquez-Hernandez LA, Murias-Rosales A, Hernández González A, Cabrera De León A, Díaz-Chico BN, Mori De Santiago M, Fernández Pérez L. 2009. Gene polymorphisms in TYMS, MTHFR, p53 and MDR1 as risk factors for breast cancer: a case-control study. Oncol Rep 22(6): 1425-1433.

45) Vainer AS, Boiarskikh UA, Voronina EN, Selezneva IA, Sinkina TV, Lazarev AF, Petrova VD, Filipenko ML. 2010. Polymorphic variants of folate metabolizing genes (C677T and A1298C MTHFR, C1420T SHMT1 and G1958A MTHFD) are not associated with the risk of breast cancer in West Siberian Region of Russia. Mol 
Biol (Mosk) 44(5): 816-823.

46) Ergul E, Sazci A, Utkan Z, Canturk NZ. 2003. Polymorphisms in the MTHFR gene are associated with breast cancer. Tumour Biol 24(6): 286-290.

47) Semenza JC, Delfino RJ, Ziogas A, Anton-Culver H. 2003. Breast cancer risk and methylenetetrahydrofolate reductase polymorphism. Breast Cancer Res Treat 77(3): 217-223.

48) Cheng CW, Yu JC, Huang CS, Shieh JC, Fu YP, Wang HW, Wu PE, Shen CY. 2008. Polymorphism of cytosolic serine hydroxymethyltransferase, estrogen and breast cancer risk among Chinese women in Taiwan. Breast Cancer Res Treat 111 (1): 145-155.

49) Suzuki T, Matsuo K, Hirose K, Hiraki A, Kawase T, Watanabe M, Yamashita T, Iwata H, Tajima K. 2008. Onecarbon metabolism-related gene polymorphisms and risk of breast cancer. Carcinogenesis 29(2): 356-362.

50) Sangrajrang S, Sato Y, Sakamoto H, Ohnami S, Khuhaprema T, Yoshida T. 2010. Genetic polymorphisms in folate and alcohol metabolism and breast cancer risk: a case-control study in Thai women. Breast Cancer Res Treat 123(3): 885-893.

51) Hosseini M, Houshmand M, Ebrahimi A. 2011. MTHFR polymorphisms and breast cancer risk. Arch Med Sci 7(1): 134-137.

52) Mohammad NS, Yedluri R, Addepalli P, Gottumukkala SR, Digumarti RR, Kutala VK. 2011. Aberrations in one-carbon metabolism induce oxidative DNA damage in sporadic breast cancer. Mol Cell Biochem 349(1-2): 159-167.

53) Akram M, Malik FA, Kayani MA. 2012. Mutational analysis of the MTHFR gene in breast cancer patients of Pakistani population. Asian Pac J Cancer Prev 13(4): 1599-1603.

54) Lajin B, Alhaj Sakur A, Ghabreau L, Alachkar A. 2012. Association of polymorphisms in one-carbon metabolizing genes with breast cancer risk in Syrian women. Tumour Biol 33(4): 1133-1139.

55) Akilzhanova A, Nurkina Z, Momynaliev K, Ramanculov E, Zhumadilov Z, Rakhypbekov T, Hayashida N, Nakashima M, Takamura N. 2013. Genetic profile and determinants of homocysteine levels in Kazakhstan patients with breast cancer. Anticancer Res 33(9): 4049-4059.

56) He JM, Pu YD, Wu YJ, Qin R, Zhang QJ, Sun YS, Zheng WW, Chen LP. 2014. Association between dietary intake of folate and MTHFR and MTR genotype with risk of breast cancer. Genet Mol Res 13(4): 8925-8931.

57) Weiwei Z, Liping C, Dequan L. 2014. Association between dietary intake of folate, vitamin B6, B12 \& MTHFR, MTR genotype and breast cancer risk. Pak J Med Sci 30(1): 106-110.

58) Awwad N, Yousef AM, Abuhaliema A, Abdalla I, Yousef M. 2015. Relationship between genetic polymorphisms in MTHFR (C677T, A1298C and their haplotypes) and the incidence of breast cancer among Jordanian females-case-control study. Asian Pac J Cancer Prev 16(12): 5007-5011.

59) Qi X, Ma X, Yang X, Fan L, Zhang Y, Zhang F, Chen L, Zhou Y, Jiang J. 2010. Methylenetetrahydrofolate reductase polymorphisms and breast cancer risk: a metaanalysis from 41 studies with 16,480 cases and 22,388 controls. Breast Cancer Res Treat 123(2): 499-506.

60) Zhong S, Chen Z, Yu X, Li W, Tang J, Zhao J. 2014. A meta-analysis of genotypes and haplotypes of methy- lenetetrahydrofolate reductase gene polymorphisms in breast cancer. Mol Biol Rep 41(9): 5775-5785.

61) Rai V. 2014. The methylenetetrahydrofolate reductase C677T polymorphism and breast cancer risk in Asian populations. Asian Pac J Cancer Prev 15(14): 5853-5860.

62) Xie SZ, Liu ZZ, Yu JH, Liu L, Wang W, Xie DL, Qin JB. 2015. Association between the MTHFR C677T polymorphism and risk of cancer: evidence from 446 casecontrol studies. Tumour Biol 36(11): 8953-8972.

63) Newberne PM, Rogers AE. 1986. Labile methyl groups and the promotion of cancer. Annu Rev Nutr 6: 407-432.

64) Selhub J, Miller JW. 1992. The pathogenesis of homocysteinemia: interruption of the coordinate regulation by S-adenosylmethionine of the remethylation and transsulfuration of homocysteine. Am J Clin Nutr 55(1): 131-138.

65) Cravo ML, Mason JB, Dayal Y, Hutchinson M, Smith D, Selhub J, Rosenberg IH. 1992. Folate deficiency enhances the development of colonic neoplasia in dimethylhydrazine-treated rats. Cancer Res 52(18): 5002-5006.

66) Fenech M, Aitken C, Rinaldi J. 1998. Folate, vitamin B12, homocysteine status and DNA damage in young Australian adults. Carcinogenesis 19(7): 1163-1171.

67) Zapisek WF, Cronin GM, Lyn-Cook BD, Poirier LA. 1992. The onset of oncogene hypomethylation in the livers of rats fed methyl-deficient, amino acid-defined diets. Carcinogenesis 13(10): 1869-1872.

68) Christensen BC, Kelsey KT, Zheng S, Houseman EA, Marsit CJ, Wrensch MR, Wiemels JL, Nelson HH, Karagas MR, Kushi LH, Kwan ML, Wiencke JK. 2010. Breast cancer DNA methylation profiles are associated with tumor size and alcohol and folate intake. PLoS Genet 6(7): e1001043.

69) Friso S. 2002. A common mutation in the 5,10-methylenetetrahydrofolate reductase gene affects genomic DNA methylation through an interaction with folate status. Proc Natl Acad Sci USA 99(8): 5606-5611.

70) Ma E, Iwasaki M, Kobayashi M, Kasuga Y, Yokoyama S, Onuma H, Nishimura H, Kusama R, Tsugane S. 2009. Dietary intake of folate, vitamin B2, vitamin B6, vitamin $\mathrm{B} 12$, genetic polymorphism of related enzymes, and risk of breast cancer: a case-control study in Japan. Nutr Cancer 61(4): 447-456.

71) Negri E, La Vecchia C, Franceschi S. 2000. Re: dietary folate consumption and breast cancer risk. J Natl Cancer Inst 92(15): 1270-1271.

72) Stevens VL, McCullough ML, Sun J, Gapstur SM. 2010. Folate and other one-carbon metabolism-related nutrients and risk of postmenopausal breast cancer in the Cancer Prevention Study II Nutrition Cohort. Am J Clin Nutr 91(6): 1708-1715.

73) Larsson SC, Bergkvist L, Wolk A. 2008. Folate intake and risk of breast cancer by estrogen and progesterone receptor status in a Swedish cohort. Cancer Epidemiol Biomarkers Prev 17(12): 3444-3449.

74) Lewis SJ, Harbord RM, Harris R, Smith GD. 2006. Metaanalyses of observational and genetic association studies of folate intakes or levels and breast cancer risk. $J$ Natl Cancer Inst 98(22): 1607-1622.

75) Tio M, Andrici J, Eslick GD. 2014. Folate intake and the risk of breast cancer: a systematic review and metaanalysis. Breast Cancer Res Treat 145(2): 513-524.

76) Zhong S, Xu J, Li W, Chen Z, Ma T, Zhao J. 2013. Methionine synthase A2756G polymorphism and breast can- 
cer risk: an up-to-date meta-analysis. Gene $\mathbf{5 2 7}(2)$ : $510-515$.

77) Niu Z, Zhao H, Hou X. 2017. Association of MTHFR, MTRR and MTR polymorphisms with breast cancer risk: A study in Chinese females. Int J Clin Exp Pathol 10(6): 7059-7066.

78) Hedayatizadeh-Omran A, Alizadeh-Navaei R, ToghaniHulari F, Amjadi O. 2017. Association between MTHFR (C677T) gene polymorphism with breast cancer in Northern Iran. WCRJ 4(2): e876.

79) Waseem M, Hussain SR, Kumar S, Serajuddin M, Mahdi F, Sonkar SK, Bansal C, Ahmad MK. 2016. Association of MTHFR (C677T) Gene polymorphism with breast cancer in North India. Biomark Cancer 8: 111-117.

80) Chou YC, Wu MH, Yu JC, Lee MS, Yang T, Shih HL, Wu TY, Sun CA. 2006. Genetic polymorphisms of the methylenetetrahydrofolate reductase gene, plasma folate levels and breast cancer susceptibility: a case-control study in Taiwan. Carcinogenesis 27(11): 2295-2300.

81) Kumar P, Yadav U, Rai V. 2015. Methylenetetrahydrofolate reductase gene $\mathrm{C} 677 \mathrm{~T}$ polymorphism and breast cancer risk: Evidence for genetic susceptibility. Meta Gene 6: 72-84.

82) Liang H, Yan Y, Li T, Li R, Li M, Li S, Qin X. 2014. Methylenetetrahydrofolate reductase polymorphisms and breast cancer risk in Chinese population: a metaanalysis of 22 case-control studies. Tumour Biol 35(2): 1695-1701.

83) Da Conceicao LL, Pessoa MC, Hermsdorff HHM, De Freitas RN, Do Carmo Gouveia Peluzio M. 2016. MTHFR and MTR polymorphisms and breast cancer in Brazilian women. World J Res Rev 2(6): 29-32.

84) Shrubsole MJ, Gao YT, Cai Q, Shu XO, Dai Q, Jin F, Zheng W. 2006. MTR and MTRR polymorphisms, dietary intake, and breast cancer risk. Cancer Epidemiol Biomarkers Prev 15(3): 586-588.

85) Hosseini M. 2013. Role of polymorphism of methyltetrahydrofolate-homocysteine methyltransferase (MTR) A2756G and breast cancer risk. Pol J Pathol 3: 191-195.

86) Stevens VL, McCullough ML, Pavluck AL, Talbot JT, Feigelson HS, Thun MJ, Calle EE. 2007. Association of polymorphisms in one-carbon metabolism genes and postmenopausal breast cancer incidence. Cancer Epidemiol Biomarkers Prev 16(6): 1140-1147.

87) Lissowska J, Gaudet MM, Brinton LA, Chanock SJ, Peplonska B, Welch R, Zatonski W, Szeszenia-Dabrowska N, Park S, Sherman M, Garcia-Closas M. 2007. Genetic polymorphisms in the one-carbon metabolism pathway and breast cancer risk: a population-based casecontrol study and meta-analyses. Int J Cancer 120(12): 2696-2703.

88) Lajous M, Romieu I, Sabia S, Boutron-Ruault MC, ClavelChapelon F. 2006. Folate, vitamin B12 and postmenopausal breast cancer in a prospective study of French women. Cancer Causes Control 17(9): 1209-1213.
89) Larsson SC, Giovannucci E, Wolk A. 2007. Folate and risk of breast cancer: a meta-analysis. J Natl Cancer Inst 99(1): 64-76.

90) Ronco A, De Stefani E, Boffetta P, Deneo-Pellegrini H, Mendilaharsu M, Leborgne F. 1999. Vegetables, fruits, and related nutrients and risk of breast cancer: a casecontrol study in Uruguay. Nutr Cancer 35(2): 111-119.

91) Baglietto L, English DR, Gertig DM, Hopper JL, Giles GG. 2005. Does dietary folate intake modify effect of alcohol consumption on breast cancer risk? Prospective cohort study. BMJ 331(7520): 807.

92) Zhu K, Davidson NE, Hunter S, Yang X, Payne-Wilks K, Roland CL, Phillips D, Bentley C, Dai M, Williams SM. 2003. Methyl-group dietary intake and risk of breast cancer among African-American women: a case-control study by methylation status of the estrogen receptor alpha genes. Cancer Causes Control 14(9): 827-836.

93) Le Marchand L, Haiman CA, Wilkens LR, Kolonel LN, Henderson BE. 2004. MTHFR polymorphisms, diet, HRT, and breast cancer risk: the multiethnic cohort study. Cancer Epidemiol Biomarkers Prev 13(12): 2071-2077.

94) Lajous M, Lazcano-Ponce E, Hernandez-Avila M, Willett W, Romieu I. 2006. Folate, vitamin B(6), and vitamin $\mathrm{B}(12)$ intake and the risk of breast cancer among Mexican women. Cancer Epidemiol Biomarkers Prev 15(3): 443-448.

95) Zhang J, Zhang L, Li G. 2016. Association between MTHFR gene 1298A $>$ C polymorphism and breast cancer susceptibility: a meta-analysis based on 38 casecontrol studies with 40,985 subjects. World J Surg Oncol 14(1): 230.

96) Rai V. 2014. Methylenetetrahydrofolate reductase A1298C polymorphism and breast cancer risk: A metaanalysis of 33 studies. Ann Med Health Sci Res 4(6): 841-851.

97) Zintzaras E. 2006. Methylenetetrahydrofolate reductase gene and susceptibility to breast cancer: a meta-analysis. Clin Genet 69(4): 327-336.

98) Lee SA, Kang D, Nishio H, Lee MJ, Kim DH, Han W, Yoo KY, Ahn SH, Choe KJ, Hirvonen A, Noh DY. 2004. Methylenetetrahydrofolate reductase polymorphism, diet, and breast cancer in Korean women. Exp Mol Med 36(2): 116-121.

99) Xu X, Gammon MD, Zhang H, Wetmur JG, Rao M, Teitelbaum SL, Britton JA, Neugut AI, Santella RM, Chen J. 2007. Polymorphisms of one-carbon-metabolizing genes and risk of breast cancer in a population-based study. Carcinogenesis 28(7): 1504-1509.

100) Xu X, Chen J. 2009. One-carbon metabolism and breast cancer: an epidemiological perspective. J Genet Genomics 36(4): 203-214.

101) Ozen F, Erdis E, Sik E, Silan F, Uludag A, Ozdemir O. 2013. Germ-line MTHFR C677T, FV H1299R and PAI-1 $5 \mathrm{G} / 4 \mathrm{G}$ variations in breast carcinoma. Asian Pac J Cancer Prev 14(5): 2903-2908. 